\title{
Mucinous colorectal carcinoma in paediatric age: an unusual diagnostic
}

\author{
Ana Aguiar Ferreira (1) , ${ }^{1}$ Susana Basso, ${ }^{1}$ Paula Gomes, ${ }^{1}$ Luis Semedo ${ }^{1,2}$
}

${ }^{1}$ Radiology, Coimbra University Hospital Centre, Coimbra, Portugal

${ }^{2}$ Faculty of Medicine, University of Coimbra, Coimbra, Portugal

\section{Correspondence to Dr Ana Aguiar Ferreira; ana.aguiar.f@gmail.com}

Accepted 18 November 2021

Check for updates

(c) BMJ Publishing Group Limited 2021. No commercial re-use. See rights and permissions. Published by BMJ.

To cite: Aguiar Ferreira A, Basso $S$, Gomes $P$, et al. BMJ Case Rep 2021;14:e246705. doi:10.1136/bcr-2021-

246705

\section{DESCRIPTION}

A 17-year-old teenager, previously healthy, with a history of a ferropenic anaemia for about 1 year, medicated with oral iron. She reports colic-like abdominal pain located in the right quadrants, starting 2 months ago, worse on decubitus. She denied other gastrointestinal symptoms, such as constipation, diarrhoea or melenas. On physical examination, a mass was palpated on the right flank, with pain on deep palpation and tenderness. Laboratory findings included normocytic normochromic anaemia (haemoglobin $10.6 \mathrm{~g} / \mathrm{L}$ ), increased $\mathrm{C}$ reactive protein $(7.85 \mathrm{mg} / \mathrm{dL})$ and sedimentation rate $(60 \mathrm{~mm} /$ hour$)$, with negative tumour markers, including carcinoembryonic antigen. Abdominal ultrasound revealed an ascending colon with irregular concentric parietal thickening along a longitudinal extension of $8 \mathrm{~cm}$ (figure 1). Abdominal and pelvic CT scan confirmed these findings and revealed bulky regional adenopathies and peritoneal implants (figure 1). She was referred to the paediatric oncology department of our institution.

Colonoscopy showed unspecific findings. An ultrasound-guided biopsy was performed and pathological anatomy revealed mucinous adenocarcinoma of colorectal phenotype.

After a multidisciplinary therapeutic decision meeting, the surgical recession was proposed and performed 10 days after being referred to our medical centre. At surgery, the cancer was localised to the ascendent colon, with bulky mesenteric adenopathies and multiple foci of carcinomatosis dispersed throughout the greater omentum. Right hemicolectomy, peritonectomy and excision of the omentum were performed. Tumour histology showed a high-grade stage IV mucinous adenocarcinoma, with infiltration of the peritoneal surface, lymphovascular and perineural invasion-pT4a pN1b pM1c (figure 2). Adjuvant chemotherapy was proposed, which the patient has already started.

Germline genetic testing revealed pathogenic alteration in PMS2 gene, including c.137G $>$ T (p.Ser46Ile) and exon 14 deletion (c.2276?_2445+?del), establishing the diagnosis of constitutional mismatch repair deficiency syndrome (CMMRD). CMMRD is a rare autosomal recessive syndrome, caused by biallelic mutations in mismatch repair genes (MSH2, MLH1, MSH6 and PMS2), contributing for the accumulation of DNA mutations, that significantly increases the risk of developing cancer in children and young adults, including colorectal carcinoma (CRC). ${ }^{1}$ The family history of cancer was obtained, showing three second-degree paternal relatives with colorectal cancer.

Mucinous CRC in paediatric age is a rare and unexpected diagnostic.

This subtype of adenocarcinoma is characterised by abundant mucinous components that comprise at least $50 \%$ of the tumour volume, differing in terms of clinical and histopathological features from other adenocarcinoma. ${ }^{2}$ It is more frequently located in the proximal colon and is the most common form of paediatric CRC. The majority has a sporadic form of the disease, usually present with non-specific signs and symptoms, often lasting 3 months until diagnosis. ${ }^{3-6}$ This greatly contributes to delayed diagnosis, with reports estimating that

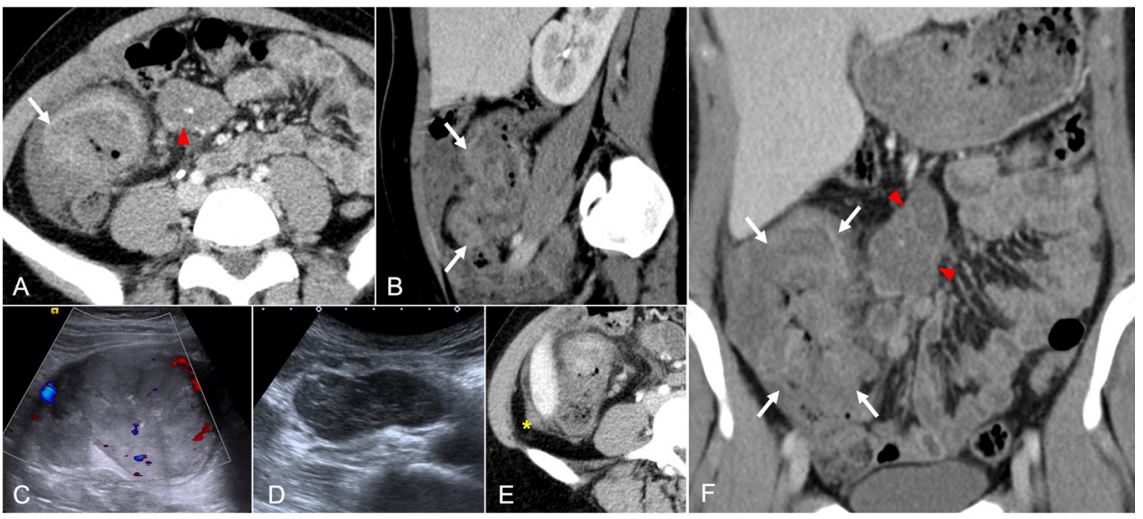

Figure 1 ( $A, B, E$ and $F) C T$ images in portal phase. A (axial image), $B$ (sagittal image) and $F$ (coronal image) show exuberant thickening of the ascending colon (arrow) and locoregional adenopathies, the largest (red arrow head) being hypodense and with punctate calcifications. E (axial image)—shows peritoneal implant (yellow asterisk) adjacent to the right hepatic border. ( $C$ and D) Ultrasound images show $(C)$ diffuse and irregular thickening of the ascending colon with internal vascularisation and (D) hypoechogenic locoregional adenopathy with punctiform calcifications. 

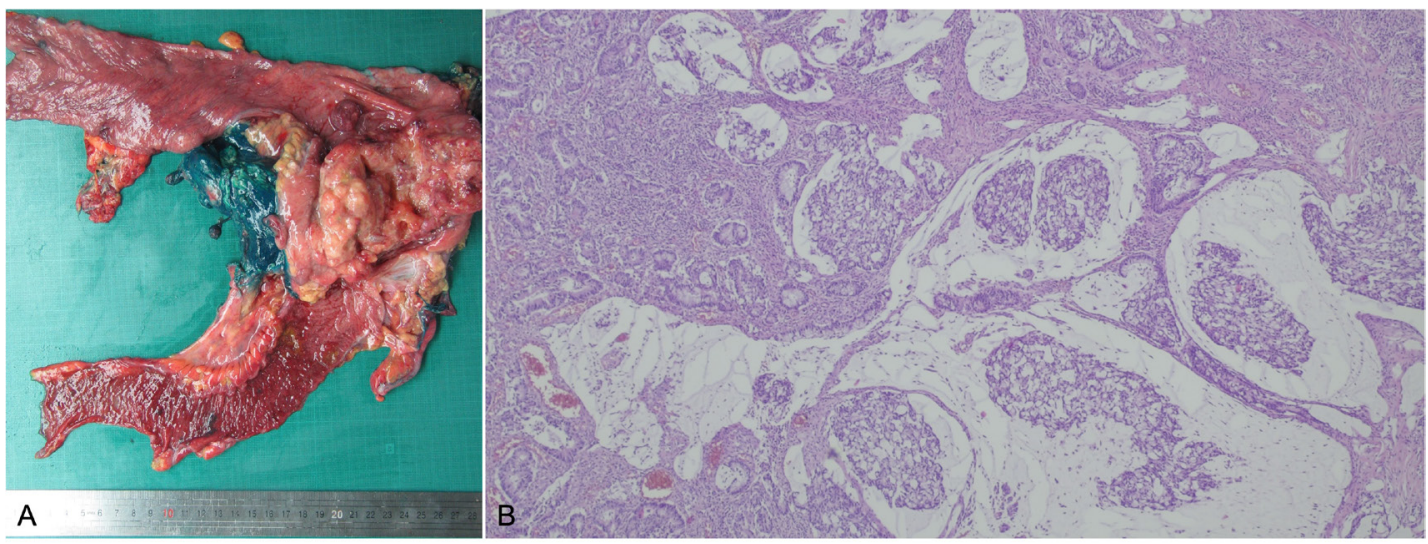

Figure 2 (A) Right hemicolectomy specimen, showing ulcerovegetative lesion. (B) (H\&E $\times 20)$ malignant epithelial lesion composed of extensive areas of mucin production; grouped cellular elements and some cells with a 'signet ring' appearance.

$60 \%-80 \%$ of children and adolescents are diagnosed in stages 3 and 4 , leading to a poor prognosis. ${ }^{5}$

Therefore, an effort must be made to alert health providers to this malignancy in children, increasing the rate of suspicion even through a non-specific clinic.

Colonoscopy is frequently recommended during investigation of CRC. However, just as in this case report, the biopsy can also be guided by other imaging modalities, such as ultrasound or CT.

The mainstay of treatment is surgery, including complete tumour resection, its lymphatic bed, and any other involved organs, which provides the greatest impact on the overall survival of the patients. ${ }^{78}$

The role of adjuvant chemotherapy and radiotherapy in children and adolescents has not been established but is recommended in advanced stages. ${ }^{8}$

Prognosis of the disease is influenced by factors such as aggressive histological subtypes, mucinous adenocarcinoma, advanced tumour grade and advanced stage of the disease. ${ }^{89}$

\section{Learning points}

- Mucinous colorectal carcinoma (CRC) is the most common histological type of CRC in the paediatric population with a known poor prognosis.

- It is a rare and unexpected diagnostic, which greatly contributes to delayed diagnosis, frequently with dissemination.

- It is important to increase the index of suspicion among doctors for an earlier diagnosis, which is the most important favourable prognostic factor.
Contributors All authors contributed to the work presented, either in the acquisition, analysis and interpretation of the data (AAF and SB), article drafting and revision (AAF, PG and $L S$ ) and final approval (PG and LS).

Funding The authors have not declared a specific grant for this research from any funding agency in the public, commercial or not-for-profit sectors.

Competing interests None declared.

Patient consent for publication Consent obtained from parent(s)/guardian(s).

Provenance and peer review Not commissioned; externally peer reviewed.

Case reports provide a valuable learning resource for the scientific community and can indicate areas of interest for future research. They should not be used in isolation to guide treatment choices or public health policy.

\section{ORCID iD}

Ana Aguiar Ferreira http://orcid.org/0000-0002-3250-9384

\section{REFERENCES}

1 Ramachandra C, Challa VR, Shetty R. Constitutional mismatch repair deficiency syndrome: do we know it? Indian J Hum Genet 2014:20:192-4.

2 Leopoldo S, Lorena B, Cinzia A, et al. Two subtypes of mucinous adenocarcinoma of the colorectum: clinicopathological and genetic features. Ann Surg Oncol 2008;15:1429-39.

3 Grady WM. Genetic testing for high-risk colon cancer patients. Gastroenterology 2003:124:1574-94

4 Vastyan AM, Walker J, Pintér AB, et al. Colorectal carcinoma in children and adolescents--a report of seven cases. Eur J Pediatr Surg 2001:11:338-41.

5 Chantada GL, Perelli VB, Lombardi MG, et al. Colorectal carcinoma in children, adolescents, and young adults. J Pediatr Hematol Oncol 2005:27:39-41.

$6 \mathrm{Ahn}$ CH, Kim SC. Two case reports: colorectal adenocarcinoma in children. Medicine 2017:96:e8074

7 Pandey A, Gangopadhyay A, Sharma S, et al. Pediatric carcinoma of rectum--Varanasi experience. Indian J Cancer 2008:45:119-22.

8 Jasperson KW, Tuohy TM, Neklason DW, et al. Hereditary and familial colon cancer. Gastroenterology 2010;138:2044-58.

9 George J, Rockall T. Surgery for colorectal cancer. Surgery 2017;3:145-50.

Copyright 2021 BMJ Publishing Group. All rights reserved. For permission to reuse any of this content visit

https://www.bmj.com/company/products-services/rights-and-licensing/permissions/

BMJ Case Report Fellows may re-use this article for personal use and teaching without any further permission.

Become a Fellow of BMJ Case Reports today and you can:

- Submit as many cases as you like

- Enjoy fast sympathetic peer review and rapid publication of accepted articles

Access all the published articles

- Re-use any of the published material for personal use and teaching without further permission

Customer Service

If you have any further queries about your subscription, please contact our customer services team on +44 (0) 2071111105 or via email at support@bmj.com.

Visit casereports.bmi.com for more articles like this and to become a Fellow 